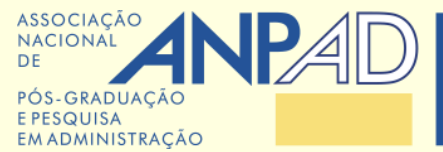

EPESQUISA

EMADMINISTRAÇÃO https://bar.anpad.org.br

BAR - Brazilian Administration Review

Vol. 16, No. 4, Art. 1, e180163, 2019

http://dx.doi.org/10.1590/1807-7692bar2019180163
BAR

Brazilian

Administration

Review

Research Article

\title{
Spatial Practices in the City: \\ The Kidnapping of an \\ Arts Organization
}

Mariana Maia Bezerra ${ }^{1}$

Luma Louise Sousa Lopes ${ }^{1}$

Joelma Soares da Silva ${ }^{1,2}$

Ana Sílvia Rocha Ipiranga ${ }^{1}$

${ }^{1}$ Universidade Estadual do Ceará, Fortaleza, CE, Brazil

${ }^{2}$ Universidade Federal do Ceará, Fortaleza, CE, Brazil

Received 21 December 2018. This paper was with the authors for one revision. Accepted 19 December 2019. First published online 23 December 2019.

Ana Rosa Camillo Aguiar was the associate editor for this article.

Editorial assistant: Luciane Kato Kiwara

Editor-in-chief: Carlo Gabriel Porto Bellini 


\begin{abstract}
Spatial practices and resistance processes play an important role in the organization of a city. In this context, we propose a study aimed at understanding the spatial practices of ruptures imbricated in the process of resistance manifested in the kidnapping of an arts organization, the April Exhibition (Salão de Abril), which is the most important art exhibition in the city of Fortaleza, Brazil. To this purpose, we used a mobile ethnography approach to single out some of the spatial practices regarding the arts organization under study. The main results reveal a network of rupture practices, which is intertwined with resistance processes in a dynamic of constitutive mutuality. This network highlights the kidnapping as a bridge to reach and include different spaces of the city that had not been practiced by the former organizers. Thus, the research contributes to an enlargement of the interlaced debate of practices, space, ruptures and resistance in the contexts of the city organizing and the Management and Organizational Studies.
\end{abstract}

Keywords: rupture; spatial practice; arts organization; kidnapping; resistance. 


\section{Introduction}

"We are already in July and the municipal government has given up on its responsibility towards the April Exhibition, but society will lead the event. Against this negligence, we invite everyone who is interested to kidnap the 68th April Exhibition" (Fórum de Artes Visuais de Fortaleza, 2017, p. 1, our translation).

When we consider the city as a social phenomenon that combines physical, social, political and symbolical dimensions, its resistance processes assume a micropolitical sphere (Certeau, 1984; Dale \& Burrell, 2008; Hall, 1988; Thomas \& Davies, 2005). Resistance often occurs as a process articulated by social groups, through a clash between the dominant power and the uniformity (Certeau, 1984; Spicer \& Böhm, 2007). For Fleming and Spicer (2007), resistance also presents a geographical aspect. The authors describe the nature of these spatial power relations, aiming to ascertain the connections between political processes and physical environments. In contexts of resistance, groups employ different practices to give voice to those who were kept in silence, and to rupture with the established dominant discourse (Certeau, 1984; Spicer \& Böhm, 2007).

Cooper (1976) discusses rupture as a changing mechanism from institutional structures that is self-generated. This rupture is usually performed by exploiting an opportunity, an "unexpected coincidence", that creates conditions for new meanings (Cooper, 1976, p. 1003). We also consider that changes and transformations that organize spaces are due to ruptures (Beyes \& Steyaert, 2012; Certeau, 1984).

Space comprises different aspects of everyday life, even when it is neither noticed nor felt. Researchers of Management and Organizational Studies (MOS) have given new perspectives and prospects to spaces (Beyes \& Steyaert, 2012; Clegg \& Kornberger, 2006; Dale \& Burrell, 2008; Greig, Gilmore, Patrick, \& Beech, 2013; Kornberger \& Clegg, 2004; Massey, 2005; Munro \& Jordan, 2013; Taylor \& Spicer, 2007; Vaujany \& Vaast, 2014).

On one hand, Certeau (1984) stresses that space only exists when practiced, otherwise it is simply a place. On the other hand, Dale and Burrell (2008) emphasize that space and place have an intimate and intertwined set of connections, both discursive and material. In this line of discussion, Beyes and Steyaert (2012) propose an alternative route to bring space back into MOS (Kornberger \& Clegg, 2004), stressing the concept of spacing based on the performative approach, which guides the understanding of spatial organization in relation to heterogeneous practice configurations.

Vaujany and Vaast (2014) also claim that both physical and immaterial elements of spacing process are intertwined by practices. Thus, in contexts of resistance, spatial practices of rupture emerge and (re)organize, (re)constitute and legitimize spaces, being fundamental to their organization as a dynamic process (Beyes \& Steyaert, 2012; Certeau, 1984; Vaujany \& Vaast, 2014).

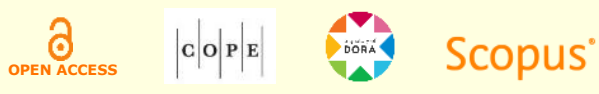


Withal and most recently, there has been an increase in work that attempts to bring the notion of spatial practices organization as a central theme for analysis in MOS. Some researchers have sketched articulations with other themes such as the creation of hybrid spaces from the practices of space appropriation (Munro \& Jordan, 2013); the organizing of spatial practices in the city (Ipiranga \& Lopes, 2017; Marins \& Ipiranga, 2017); resistance in the work environment (Yukkwan Ng \& Höpfl, 2011); the remodeling of urban practices through festivals such as Carnival (Johansson \& Kocieatkiewicz, 2011) and the rupture with the alienation processes underlying labor relations (Gouvêa \& Ichikawa, 2015). However, despite being acknowledged as an important concept, there is still a research gap in MOS since spatial practices underlie the relationship of constitutive mutuality between rupture and resistance perpetrated by organizations in the context of the city.

Considering the city as an open, polysemic and organizational phenomenon, where groups practice various forms of organization (Certeau, 1984; Vaujany \& Vaast, 2014), the April Exhibition, an arts organization, is the primary venue for the display of works of art in the city of Fortaleza, Brazil. Not only does the organization serve as a means to expose the work of dozens of artists every year, it also plays a crucial role in the development of the local arts community since its beginning. In this sense, the April Exhibition was considered here as an institutionalized arts organization that permeates creative, economic and social aspects (Flach \& Antonello, 2011), which transcends time, space and places to which it is proposed. Artistic and cultural organizations are constituted by networks of interactions of different formats, which act in the amplification of their social senses and in the revitalization of the local creative economies (Carradini, 2018).

Thus, in the light of this interlaced debate in the context of cities, we propose a study aimed at understanding the spatial practices of ruptures imbricated in the process of resistance manifested in the kidnapping of an arts organization. We assume that these spatial rupture practices relate to resistance processes in a dynamic of constitutive mutuality.

The arts organization April Exhibition was created in 1943 by a group of students as an attempt to promote local culture, and it is considered today one of the most traditional events in the national artistic calendar (Rolim, 2010). It has been organized annually by the municipal government since 1964, accounting for more than 60 editions over the years. However, in 2017, given the lack of initiative from the municipal government regarding the organization of the 2017 edition, a group of artists questioned the indifference of the public administration towards arts and decided to kidnap the organizing of the April Exhibition.

Thus, in August 2017, the artists started organizing the 68th Kidnapped April Exhibition (68 Salão de Abril Sequestrado), as an attempt to both preserve the history and importance of this arts organization in the city and give voice to numerous artists who were discontented with the current views of the public administration regarding arts (Costa, 2017; Medeiros, 2012). During its planning and execution, the Kidnapped April Exhibition has shown considerable differences to its counterpart organized by the municipal government, such as the use and inclusion of multiple places and spaces around the city for the display of the works of art.

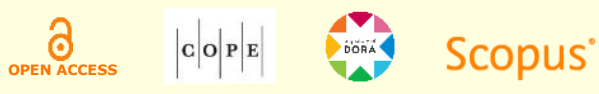


In addition to this introduction, in the next section, we present the theoretical background by discussing the issues of spatial practices in cities' organizing. Next, we discuss arts organizations. The methodological procedures are then presented, followed by the analysis, interpretations and discussion. Finally, we present our concluding remarks.

\section{Spatial Practices of Ruptures in Cities' Organizing}

The dilemmas and utopias of cities are represented in various dimensions of social life, which include their history and planning (Hall, 1988). If, on the one hand, urban space becomes a place for an articulation of diverse interests, such as economical, political and technological, on the other hand, it also presents itself as places of passage, mobility, encounter, conviviality and expression of the people and the community (Certeau, 1984; Cresswell \& Merrim, 2011; Ipiranga \& Lopes, 2017; Oliveira \& Cavedon, 2017; Saraiva \& Carrieri, 2012).

As a result of a bricolage of ways of doing things, cities can be considered as an open and polysemic social construction, which only exists when practiced by the people (Certeau, 1984; Vaujany \& Vaast, 2014). Thus, the reality is constituted by a set of practices capable of, on the one hand, generating dominant institutional discourses and, on the other hand, transforming the contexts in which they are inserted (Certeau, 1984; Spicer \& Böhm, 2007).

Practices are formed by a combination of organized activities that are timely and spatially situated, reflecting how spaces in a city are organized and how places are practiced (Certeau, 1984; Cooper, 1976; Cooper \& Fox, 1990). In this context, and more recently, Beyes and Steyaert (2012) align themselves with attempts to bring space back to the critical theory of organization (Kornberger $\&$ Clegg, 2004), shifting the discussion from the socio-spatial perspective, according to Lefebvre (1991), to a mode of non-representational theorizing (Thrift, 2007).

Inspired by an aesthetic of waiting and surprise, the authors propose to enrich the theorization and researching on organizational space with the notion of spacing. Beyes and Steyaert (2012) explain that as the gerundial form indicates, the notion of spacing is similar to the welldocumented conceptual shift from organization to organizing proposed by Czarniawska (2008). The organization of spacing implies "rethinking of space as a heterogeneous composition of forces, processual and performative, open-ended and multiple, practiced and of the everyday" (Beyes \& Steyaert, 2012, p. 47).

Thus, the everyday practices can be seen as textures, reflecting the constitution of processes and organizing structures of the daily life through a continuous movement of action (Certeau, 1984; Cooper, 1976; Cooper \& Fox, 1990). The practices enunciate action and organize the everyday life in different ways, where each practice circumscribes a knowledge, in some cases not yet clarified, but which fills the everyday life with meaning and symbolism (Certeau, 1984). In the context of city spaces, practices also assume an organizational aspect (Beyes \& Steyaert, 2012; Certeau, 1984; Dale \& Burrel, 2008; Vaujany \& Vaast, 2014). Hence, spatial practices configure a heterogeneous network that is established by the interaction between people, materials and

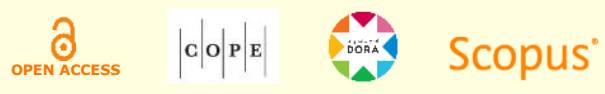


resources, which provides the basic understanding of the world (Thrift, 2007), and, to this work, the understanding of city organizing.

On the one hand, practices can take on an organizational power, capable of giving order to a spatial context (physical, economic, social and political) through an institutionalized status, considered as natural and perpetuated by collective experiences and narratives over time, through a normative power (Certeau, 1984; Fleming \& Spicer, 2007). In this sense, these regulatory practices, which Certeau (1984) refers to as strategies, are directly based on objectivity and rationality, seeking to bring legitimacy to the ways of doing. On the other hand, practices may also manifest ruptures, reflecting forms of resistance to an institutionalized system. Thus, the rupture can be seen as a practice of adaptation, subversion and re-registration, through which people move meanings and understandings. The practices can be perceived through tactical dexterities, which drive to a symbolical or institutional break with the creation of deviations (Certeau, 1984; Cooper, 1976; Spicer \& Böhm, 2007; Thomas \& Davies, 2005).

Hence, these practices seek to circumvent the rationalizing order of things by performing spacing and (re)appropriations within the network of practices that constitute everyday life (Beyes \& Steyaert, 2012; Certeau, 1984; Fleming \& Spicer, 2007; Spicer \& Böhm, 2007). This network of practices is enacted through a series of goals, bits of intelligence, and happenings that create conditions for the establishment of new manners and meanings for the (re)organizing of the everyday life, including the city space (Certeau, 1984; Cooper, 1976). Such practices lead to ruptures with the dominant discourse in the context of the city, revealing tactics and ways of historical or symbolical resistance able to (re)organize the city space (Beyes \& Steyaert, 2012; Certeau, 1984; Cooper, 1976; Dale \& Burrell, 2008; Massey, 1995; Thrift, 2007).

In this context, the practices have their own tenacity, carrying a "logical touch" (Certeau, 1984, p. 145) built from pre-reflexive experiences and imbued with a daily inventiveness that goes beyond coercive normativity of regulatory practices. The tactics expressed by the weakest are filled with knowing that serves as a mobility method exercised on an apprehended occasion, an unexpected coincidence, performed by exploiting an opportunity or even on a movement that resists and dissimulates, which can be seen as a practice of rupture (Certeau, 1984; Cooper, 1976).

These tactics have no place to be expressed but the place of the other. In this case, the strongest example may be a public institution, where the weak exercise of resistance movements creates surprises and transforms places through a set of deviations (Beyes \& Steyaert, 2012; Certeau, 1984; Cooper, 1976; Spicer \& Böhm, 2007). Hence, these practices, characterized as tactical-type, can only be determined by the absence of power. Within the space controlled by the other, the weaker performs movement by means of wiles of intelligence (Certeau, 1984; Détienne \& Vernant, 2008).

As mentioned before, resistance assumes a micropolitical sphere when we understand the city as a social phenomenon (Certeau, 1984; Dale \& Burrell, 2008; Fleming \& Spicer, 2007; Hall, 1988; Spicer \& Böhm, 2007; Thomas \& Davies, 2005). In this sense, space is also an arena of power dispute, where ordinary subjects change the rules through scams and bids, unraveling a network

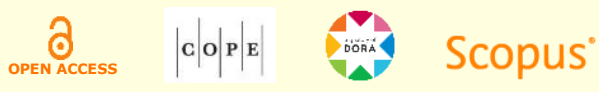


of established forces and struggles, expressing forms of mobility that regulatory practices try to fix (Certeau, 1984; Cooper \& Fox, 1990; Cresswell \& Merrim, 2011; Oliveira \& Cavedon, 2017; Panayiotou \& Kafiris, 2011).

According to Certeau (1984), and considering this dynamic of transformations, the tales of spaces have also the role of authorizing the establishment of deviations or transcendence of limits and borders. In this sense, the tales of space: (a) open a legitimate theater for practical actions; (b) are animated by a dynamic contradiction that lies between the frontier and the bridge, that is, between a space (legitimate) and its exteriority (strange). This contradiction is understood from a clash of practices by which the agents (re)appropriate spaces (Certeau, 1984). In this context, Certeau (1984) posed the question: To whom does the frontier belong?

Terdiman (2001), discussing the question of margins in Certeau, emphasizes the importance of boundaries for historical and interpretive sensitivity. The boundaries are in constant transformation, metamorphosing topologies and shaping temporalities. It is at the frontiers where possible meanings materialize, being meanings of an effect of these borders. In the field of MOS, some studies have illuminated the issues of space organizing on the borders. The border zones are the boundaries between different types of habitable spaces (Dale \& Burrell, 2008). Fleming and Spice (2007) point to a spatial blurring in these organizational configuration processes, featuring the emergence of hybrid spaces (Halford \& Leonard, 2005; Wapshott \& Mallett, 2012) where the organizational boundaries between frontier and bridges are porous, plural, differentiated, ambiguous, source of contestation, and objects of continuous negotiations.

In this context, Munro and Jordan (2013), for example, investigated spatial tactics that artists use to create hybrid workspaces within public spaces. Thus, based on an ethnography of street artists' work in an English city, the authors concluded that artists use a distinct set of spatial tactics to create a smooth space by appropriating and socializing a hybrid public space. The main contribution of the paper is the development of a procedural perception of how hybrid workspaces are created by artists through embedded spatial tactics and how these tactics exploit ambiguities at the spatial frontiers of existing urban space. The work of Munro and Jordan (2013), however, focused mainly on the relationship between practices and the transformation of space, without considering possible processes of resistance and their ruptures.

Other studies illuminate organizational boundaries and the use of spatial practices in the city, such as the work by Marins and Ipiranga (2017) and Ipiranga and Lopes (2017). The main findings of the first paper reveal the organizing of a Photography School expanded by different practices, which creates bridges beyond the boundaries between urban spaces. On the latter, through a study of aesthetic awareness, the authors highlight a network of historical and festive practices that organize spaces of boundaries in a city square. These studies focus on how spaces are appropriated and organized by practices, considering different concepts of Michel de Certeau and other authors of the MOS field. 
Some other articles raised in the databases consulted, such as the study of Yuk-kwan $\mathrm{Ng}$ and Höpfl (2011), have articulated resistance in the workplace as a result of appropriation practices of the work context by the insertion of personal objects (family photos, children's drawings, among others). Based on an interpretative approach and usage of photography, the authors examine the workspace modification practices that cherish the condition of exile and, at the same time, function as a form of resistance.

Johansson and Kocieatkiewicz (2011) examined the tensions between the production of controlled images, the Carnival celebration and the extent to which meanings and urban spaces can be managed. The paper critically presents the possibility of remodeling urban practices through the staging of the festival and the potential for creativity and expression in the managed presentation of the experience. The paper used the theoretical foundation of everyday life proposed by Certeau (1984), arguing that urban practices sustain the city's daily life, while festivals occur in parallel, making the city a process for circulation, combination and recombination of people and things (Johansson \& Kocieatkiewicz, 2011).

Finally, we also highlight the work of Gouvêa and Ichikawa (2015), which defends the rupture as alienation processes underlying labor relations. From the idea that everyday life is a space of invention and resistance, people weave their own histories and break the typical uniformity with practices that manifest microresistances. Obtained by observing participation, the main findings state that the cooperative organization is a game of interests where the alienation emerges in the actions taken by the cooperative and by the cooperative itself. This context favors the emergence of daily tactics that serve capitalist discourse. The main theoretical contribution of the study is related to daily life, which interweaves several perspectives in one direction.

Even though these discussions extended the debate on varieties of practices, the notion of practices of rupture in the cities' organizing and their constitutive mutuality with the resistance process are not considered. In this sense, we seek to contribute to the frontiers of knowledge in MOS by fomenting those discussions about cities' organizing, through the analysis of an arts organization.

\section{Arts Organization}

Considering the goals of this study, we articulate the following discussions about arts organizations that permeate the creative industries' sector, which can be associated with economic information and production of cultural goods (D'astous, Colber, \& Fournier, 2007; Flach \& Antonello, 2011; Rentschler \& Potter, 1996). Many authors use the term as a synonym for cultural organizations or associated with it, such as Flach and Antonello (2011) and D'astous, Colber and Fournier (2007). Flach and Antonello (2011) emphasize that these organizations are located in a cultural and artistic circuit, with the characteristic of not having a large-scale production. D'astous et al. (2007) associate the term with cultural production and exemplify these organizations through museums, theatres and symphony orchestras. In counterpoint, Goulart, Menezes and Gonçalves (2002) argue that arts organizations are being seen less as an economic

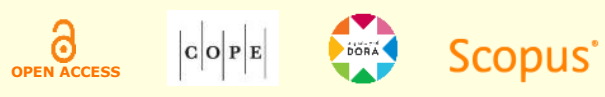


activity and more as social and cultural vies. According to these authors, an economic path is still being constructed.

For this study, we understand the April Exhibition as an organization of the artistic sector, in which the artists produce artifacts such as paintings, sculptures, photos, installations and performances. Besides that, we comprehend the arts organizations' concept beyond the walls, as an open, processual and diffuse phenomenon, related to the act of organizing. In this sense, it acts as a network composed of actors and groups with different artistic notions and interests (Cooper, 1976; Czarniawska, 2008).

In the art circuit of Fortaleza in particular, Medeiros (2012) makes criticism to the fact that the city's art system is not yet fully developed and that there are no mechanisms of continuity for artists and members of the field. As for the many different arts organizations in Fortaleza, and especially for those who adhere to the visual arts, the author also emphasizes how the visual arts are highly dependent on state funding, which is provided through public policies.

Regarding the April Exhibition, Machado (2011) describes the 59th edition, which was organized not only inside the walls of a gallery but also in an urban transport terminal in the city. The author problematizes the discussions about educational actions through the dialectic between art and the public. The results of the study showed that those actions are challenging and stimulating in the sense of expanding and going beyond the daily spaces of the city, enabling people to access art as a possible way of understanding and transforming the world around us (Machado, 2011).

\section{Methodology}

The Kidnapped April Exhibition was organized in a series of meetings, where artists, curators and coordinators met to plan the logistics in the context of the city. In these meetings, there were discussions regarding the venues in which the works of art would be exposed, the layout of each exposition, the artists exposing in each venue and the works of art themselves. In addition, the encounters were held in different urban spaces that were (re)appropriated for this arts organization, denoting the creation of a set of spatial deviations (Beyes \& Steyaert, 2012; Spicer \& Böhm, 2007).

These meetings started in late July 2017 and were arranged until late September, when the Kidnapped April Exhibition was opened to the public. As mentioned before, the Kidnapped Exhibition was not organized by the municipal government. Therefore, since the 2017 edition the event did not have any funding, the organizing completely relied on donations and collaborations.

In total, the Kidnapped April Exhibition organizing involved 158 artists, whose works were exposed in 15 different spaces around the city of Fortaleza, where each of them was properly included and adapted to host an artistic exposition. The Kidnapped Exhibition opened to the public from September 28 to October 28, 2017.

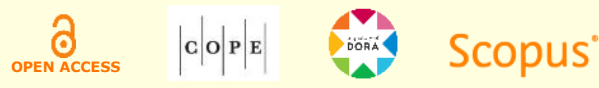


We based our qualitative and descriptive paper on mobile ethnography (Czarniawska, 2007; Marcus, 1995). We conducted the fieldwork between September 15 and October 28, 2017, with all the authors actively involved in data collection. Our process invited us to build rich corpus data relying on field observations, interviews and archival sources.

Fieldwork started with our participant and non-participant observations in the organizing of Kidnapped April Exhibition, in which we attended meetings, participated and observed the creation of different spaced practices in the city, and joined the assembly of some of the exposition venues of the event. We also visited the exposition venues while the Kidnapped April Exhibition was open to the public. Thus, we were able to immerse ourselves in the urban spaces that were gradually involved in the field of this study through mobile, direct and participant observations.

Overall, we perceived 20 visits to the field in which eight were participant observations and 12 non-participant observations, with our respective field notes. In those visits, we used walks as a method to map the set of spaces and practices that were performed in the city (Certeau, 1984). During these walks, we occasionally interviewed three artists, two curators and two organizers who were exposing and/or working in the Kidnapped Exhibition organization. Furthermore, we conducted one in-depth semi-structured interview with one of the organizers of the Exhibition and produced some photographic images. We chose these subjects because they were involved in the kidnapping since its beginning.

We considered this organization as a historical practice (Certeau, 1984) since the first April Exhibition took place in 1943. Therefore, we consulted three archival sources searching for public and private documents and we collected 25 documents referent to the Exhibition, such as newspaper articles, books, manifestos, papers, catalogues and reports. These documents were selected because they are related to the April Exhibition historical path and/or to the Kidnapped April Exhibition.

After a first descriptive analysis aiming to understand the sequence of historical events about the April Exhibition and how it unfolds over time, we proceeded the identification of a set of practices developed during the Kidnapped April Exhibition from our field notes and observations (Certeau, 1984). These practices created a set of spatial deviations from the ones previously performed by the municipal government that based our analysis.

Therefore, in order to analyse and to understand the spatial practices of rupture that emerged from our observations and other procedures, we resort to the theorizing operation proposed by Certeau (1984). We employed the "cut-out and turn-over" method, where an initial collection of previously unknown practices is enlightened through discourse (Certeau, 1984, p. 62). In this sense, the operational schema of analysis was composed of these two complementary movements: cut out and turn over. 
First, we highlighted the spatial practices of rupture and the resistance processes of the arts organization in the context of the city. Highlighted, these practices and processes form an isolated and obscure body compared to its place of origin. Second, we inverted those obscure practices and processes in a unit able to illuminate the theory. Thus, spatial practices of rupture and resistance process have their content converged into luminous writing (Certeau, 1984).

\section{Main Findings}

The Kidnapped April Exhibition comprised a multitude of spaces and places, works of art and a set of practices that together form a dense corpus of information to be described. Thus, we initially chose to bring a summary of the historical context of the event, highlighting its main nuances of resistance process. Furthermore, we present the main practices from our analysis that represent spatial practices of ruptures.

\section{The kidnapping of an arts organization: a brief history of resistance}

The first edition of April Exhibition happened in 1943, and it was organized by a group of students, where works of art by local artists were showed. Its second edition happened three years later, in 1946. By that time, a group of artists has found an association with the aim of not only promoting the visual arts and bringing artists closer together but also with the intention of organizing the April Exhibition itself (Rolim, 2010). The artistic movement in this period grew out, and it was able to reveal that "there is a painter at any corner" (Estrigas, 1983, p. 27, our translation).

The organizing of the Exhibition began to function as an arts organization for the promotion and recognition of local art at the time (D'astous et al., 2007; Flach \& Antonello, 2011; Rentschler \& Potter, 1996). The essence of this arts organization can be described in the following two excerpts. The first one was taken from a newspaper of 1947. "The III April Exhibition has received an increasing number of attendees, rounding it up to the thousands, as proof of the great and justified interest that the exhibition has been awakening in the most varied social circles" (O III Salão de Abril está sendo muito visitado pelo nosso povo, 1947, our translation). The second excerpt was singled out from a book published in 2010 that described the positioning of the event in a broader context. "We reinforce this inclination of the April Exhibition, from its beginning, to insert itself in the intricacies of Brazilian art, underlining the presence of the artists who participated in its first edition and fit in the national and even international context" (Rolim, 2010, p. 37, our translation).

In 1953, after several complaints about the lack of support from the municipal government, the April Exhibition got the attention of the official power. This was due to a strong relationship between the mayor, by the time, and one of the organizers. The financial support was directed to the assembly of the Exhibition and to some of the artists as awards. In addition, it was decided that April 13 would be the opening day, as this was the city's anniversary. However, this funding only lasted until the end of the mayor's mandate (Estrigas, 1983).

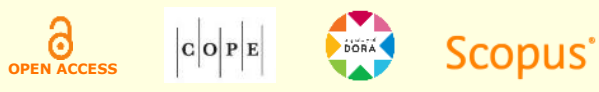


For lack of money and support, the last edition organized by the artists happened in 1958. The April Exhibition was then picked up again by the municipal government in 1964. Since then, it has been organized every year, when the artists undergo a selection process and compete for awards, often given in cash. It is noteworthy that, after this return under the leadership of the city hall in 1964, the April Exhibition organizing has been continuously hosted in institutionalized places, as well as being part of the city's Ministry of Culture (Certeau, 1984; Vaujany \& Vaast, 2014). For the last 7 years, the April Exhibition has been officially organized in only two places in the city, both of them equipments of the public power.

However, in 2017, the municipal government remained silent about the organization of that year's edition. Thus, the artists themselves gathered and, by combining their strengths and concerns not only with the realization of the April Exhibition but also with the cultural and artistic scene in the city, decided to kidnap the April Exhibition. This can be observed in the following three excerpts. The first one was taken from a public manifesto that the organizers published in a Facebook account, explaining the kidnapping as "an initiative to address the absence of public policies in the area of culture and more specifically of the visual art" (Fórum de Artes Visuais de Fortaleza, 2017, p. 1, our translation). The second excerpt, from the same Facebook account, reinforces their intentions towards the Kidnapped April Exhibition and is addressed to the city's Culture Department, which is responsible for the city's cultural equipment and projects: "The artistic movement manifests our willing to do more for the visual arts in the city. Also, it sets forth our dissatisfaction with the lack of attitude from the city's Ministry of Culture" (68 Salão de Abril Sequestrado, 2017a, our translation). The third excerpt comes from an interview that was realized with one of the organizers. She draws the context in which the kidnapping happened.

\footnotetext{
"We have seen that the cultural public policies, especially towards the arts, have been increasingly lacking .... The person who won the award in the last April Exhibition only received his cash prize recently .... So, this movement was extremely necessary to bring attention to the arts, and state that 'something needs to be done for the visual arts otherwise they could vanish'. At any time, they can drop out the little incentive that we have. We are living in difficult and dark times for art." (Interview, 2017, our translation).
}

These excerpts reveal that the ideas behind the kidnapping go beyond the April Exhibition organizing itself; they reside as resistance from the artists in the protection of the artistic scene in the city, against the city's Ministry of Culture and the municipal government (lack of) support. In this sense, the artists, in a political movement, were held together by a common sense of purpose (Fleming \& Spicer, 2007; Spicer \& Böhm, 2007; Thomas \& Davies, 2005). This can be clearly seen in a Facebook post stating that "after all, we are building this Exhibition together and thinking in ways to exist collectively" (68 Salão de Abril Sequestrado, 2017b, our translation).

The organization was characterized as unpredictable by one of the curators during a meeting. The curator added that the organizing was "creative, unexpected and full of surprises." The unpredictability of this edition was depicted by the organizing of the largest April Exhibition to date, involving 158 artists and 15 appropriated spaces in the city, regardless of the extreme lack of resources. This sense of surprise and unexpectedness is based on the tactic's logic expressed by

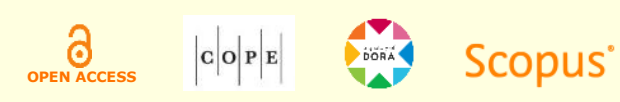


the weakest by means of an apprehended occasion, an unexpected coincidence performed by exploiting an opportunity or even a movement that resists and dissimulates (Certeau, 1984; Cooper, 1976; Spicer \& Böhm, 2007).

By their resistance process, the artists turned the silence of the municipal government into a chance/occasion/coincidence/opportunity to expose simultaneously their tactics and strategic interests (Certeau, 1984; Gouvêa \& Ichikawa, 2015; Munro \& Jordan, 2013; Yuk-kwan Ng \& Höpfl, 2011). This can be better described through an excerpt from the field notes of one of the meetings.

According to field notes from September 15, 2017, the idea (of the Kidnapped Exhibition) is to show that the artists have strength. The kidnapping is also a kind of protest in order to reveal the dissatisfaction with the way that the April Exhibition has been organized: being hosted at a single place, giving cash as award and picking the works of art through closed selection processes.

The kidnapped arts organizing indicates a set of practices with predominance of the tactical type, based on wiles of intelligence (Certeau, 1984; Détienne \& Vernant, 2008; Ipiranga \& Lopes, 2017), which rewrite the institutionalized strategies and practices from the municipal government and show what can be done differently (Certeau, 1984; Spicer \& Böhm, 2007; Vaujany \& Vaast 2014). Thus, the kidnapping is an enactment of a resistance process that brought out a delinquent practice and a liberating rupture (Certeau, 1984; Cooper, 1976), as well as a subversive and reversible process of dominant discourse from the municipal government by the ordinary (Certeau, 1984; Thomas \& Davies, 2005).

We further note that when asked about the Kidnapped April Exhibition, one of the organizers said that they "didn't have much" and that they "intended to do more but had to take a measured stance in the face of the lack of resources." So, in addition to this unpredictability, collaborations and donations were accepted in the Kidnapped April Exhibition, mostly in the form of volunteering work (Certeau, 1984). This also represents a significant change when compared to the average of 30 artists, a single art gallery and a larger budget in the previous editions organized by the municipal government (Cooper, 1976). This process heavily influenced the April Exhibition expansion, based on a set of spatial deviations, involving the (re)appropriation of different places around the city, with the aim of practicing these places to host the kidnapped arts organization (Beyes \& Steyaert, 2012; Certeau, 1984; Spicer \& Böhm, 2007).

Hence, the resistance displayed by the kidnapping broke down barriers and disconnected from what has been accomplished to the expanded borders, opening new frontiers between different types of spaces as a source of contestation and object of continuous negotiations (Dale \& Burrell, 2008; Fleming \& Spicer, 2007; Halford \& Leonard, 2005; Wapshott \& Mallett, 2012). In this case, the movement of resistance also assumes a micropolitical sphere when we understand the city as practical phenomenon (Certeau, 1984; Hall, 1988; Spicer \& Böhm, 2007; Thomas \& Davies, 2005).

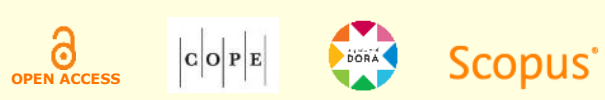




\section{The network of heterogeneous practices and their effects on the city organizing}

The way of speaking, that is, the discursive practices of the actors involved during the kidnapped arts organization, turned their voices into a song of resistance (Certeau, 1984). We noticed this through the constant use of specific speeches, such as "kidnapping", "we will kidnap", and "the exhibition is kidnapped". Terdiman (2001) discussed the question of margins in Certeau (1984), emphasizing the importance of boundaries for historical and interpretive sensitivity, as well as considering the discursive practice used by actors in the everyday context as a tale of space. The tale of spaces has the role of authorizing the establishment of deviations or transcendence of the borders, opening a legitimate theatre for a mesh of practices by which the agents (re)appropriate spaces (Certeau, 1984; Vaujany \& Vaast, 2014).

At the meetings, the group of actors involved in the kidnapping showed a great intention of spreading the Kidnapped Exhibition throughout the city inasmuch as "it has to be this way, it wasn't possible to think of an exhibition happening in a single place", according to one of the organizers in the interview. Moreover, these discursive practices or tales of spaces revealed spatial practices of rupture that occur by changing what was established and revealing a set of spatial deviations as spacing, inclusion and (re)appropriation process (Cooper, 1976; Terdiman, 2001).

Hence, they constitute a tactical practice of the ordinary that ruptured with the discourse that was established from the institutionalized strategic practices enacted by the municipal government (Certeau, 1984; Cooper, 1976). To reinforce these tales of rupture practices, we single out an excerpt from an online newspaper, where one of the organizers described the movement of spacing, (re)appropriation and (re)organization, and the inclusion of different spaces around the city, highlighting the unfolding in terms of spatial practices:

According to field notes from October 24, 2017, the curators and artists expressed that they found to make the Exhibition from a perspective of inclusion, in a way of moving the works of art through the city, since the intention was to circulate a work of art that is not usually inside the circuit of the galleries.

Thus, the tales of space served not only as a milestone to promote the kidnapping, but also remained throughout the trajectory of the arts organization, expanding borders and building bridges through artistic performances and urban interventions (Certeau, 1984; Terdiman, 2001). This heterogeneous set of practices acted in the processes of deviations, spacing, inclusion, (re)appropriation and (re)organization of different spaces around the city occurred by artistic practices that interacted with local communities, such as: walks through neighborhoods, live performances and wheat paste collages, among others. This was exemplified in a performance realized in the church of a local community.

In this act (Figure 1), the artist invited children from the community to deconstruct his work of art. In doing so, these artistic practices closed the gap, building bridges, between artists and local population, occupying, (re)appropriating and (re)organizing spaces in the city while performing these practices (Beyes \& Steyaert, 2012; Certeau, 1984; Fleming \& Spicer, 2007; Machado, 2011;

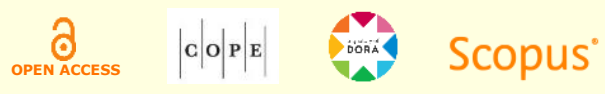


Wapshott \& Mallett, 2012). These practices are characterized as spatial practices of rupture by (re)signifying city spaces in their political, artistic and educational connotations (Certeau, 1984; Cooper, 1976).

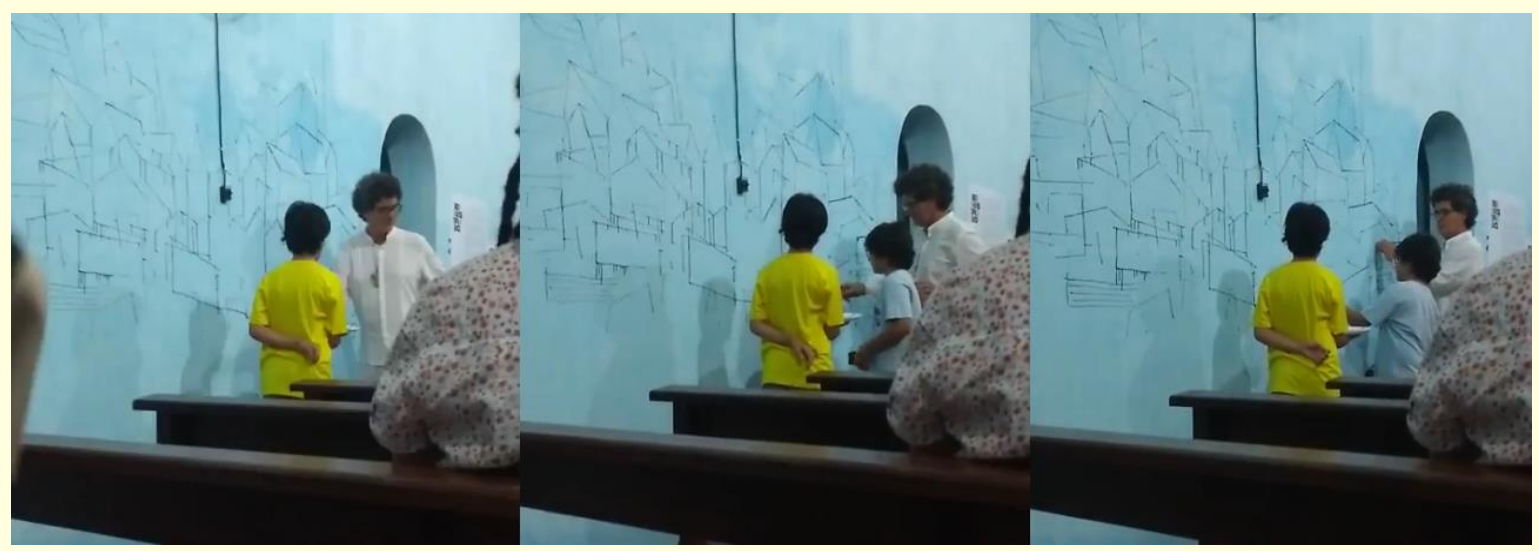

Figure 1. Performance realized in the community church

The choice of some spaces was based on the significance of its inclusion in the processes of an arts organization and its effects on the city. The kidnapping (re)appropriated and (re)organized spaces that were thought as marginalized, in favor of the inclusion of peripheral urban districts. Because of this dynamic, the borders of the April Exhibition have been extended by creating new venues, showing more works of art and engaging more artists, revealing a heterogeneous, simultaneous and complementary network of tactical and strategic practices (Certeau, 1984; Halford \& Leonard, 2005).

The Kidnapped April Exhibition organizing had access and appropriated a total of 15 different spaces in the city to carry out the exhibition, including spaces not originally designed to host artrelated events. The set of practiced spaces included: galleries and schools of art, cultural centers, museums, local communities, a church, a coworking facility, local communities and an ecological park.

We also emphasize that none of these spaces had an institutional link with the government, waving to an institutional characterization as one of the mottos of the arts organizing. This can be noticed in the two following excerpts: "We are working without any money, everyone is donating their workforce and the event will happen only in non-governmental spaces" (68 Salão de Abril começa hoje, 2017, our translation) and "... one of the decisions that we made was not to accept any kind of space linked to the public power, right? To the government... state, city hall" (Interview, 2017, our translation).

This set of spaces had multiple meanings, reflecting the call for greater integration of the local political scene and the artistic scene, characterizing a resistance movement and understanding the city as a practical phenomenon (Beyes \& Steyaert, 2012; Certeau, 1984; Hall, 1988; Spicer \& Böhm, 2007; Thomas \& Davies, 2005). This plurality of practiced spaces is an aspect that distinguishes and breaks the organization of the Kidnapped Exhibition from its previous editions.

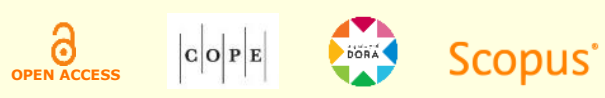


This can be seen in the map below (Figure 2), drawn in the Google Maps platform. The two blue pointers indicate the space practiced by the April Exhibition since 2010 by the municipal government. The 14 orange pointers indicate the effects of spacing, inclusion, (re)appropriation and (re)organization of spaces by the Kidnapped Exhibition, reveling spatial practices of ruptures around the city.

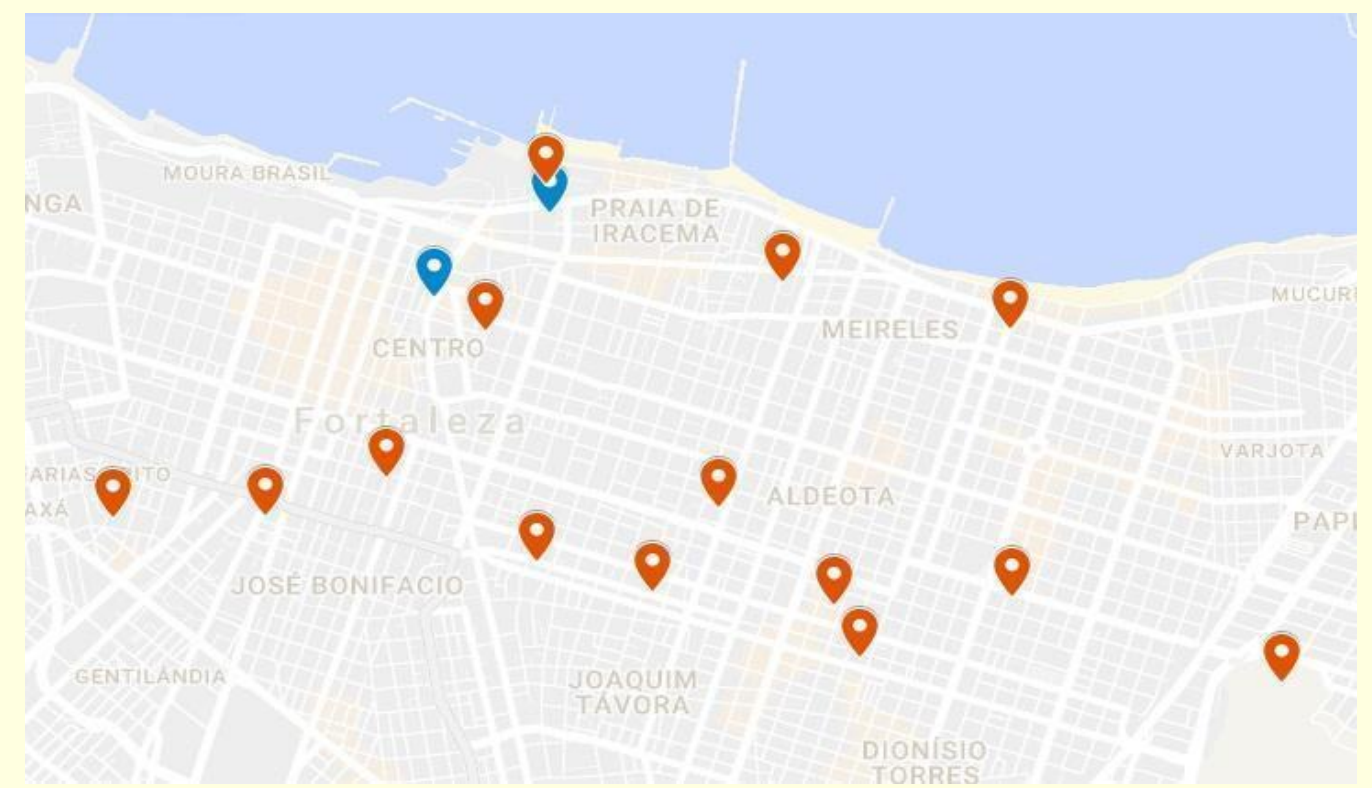

Figure 2. Spacing practices in the city organizing

Source: adapted from 68ㅇ Salão de Abril Sequestrado. (n.d.). Mapa 680 Salão de Abril Sequestrado. Retrieved from https://www.google.com/maps/d/embed?mid=1vb_a7OjosOsSy5usCfwllO058W4

This difference between the Kidnapped Exhibition organizing and the official one can also be noticed in the following excerpt from the field notes. According to field notes from September 16, 2017, one of the curators said that the Kidnapped Exhibition broke up with the basic format. He also emphasized that the arts organizing was open to various actions beyond the places where the exhibitions were going to happen. Since many of the spaces act independently, they do not have operational guidelines, as is the case with institutionalized places.

Thus, the kidnapped arts organization broke up with a practice already institutionalized by the city hall, that is, the realization of the Exhibition in a single space, weaving a mesh of heterogeneous practices that built bridges between different spaces, (re)appropriating and including new spaces (Certeau, 1984; Cooper, 1976; Fleming \& Spicer, 2007). Artistic practices, in this sense, created new uses and meanings intertwined in the city through the construction of a proper place in terms of art, reorganizing the everyday urban life.

In addition to the multiplicity of practiced spaces (Certeau, 1984), we also observe a diversity of identity practices in the places of exposure that were (re)appropriated in these processes (Beyes \& Steyaert, 2012; Cooper, 1976; Terdiman, 2001). We further note that for the occasion of the Kidnapped April Exhibition, some spaces had their identities modified in order to attend the collective goal of the arts organization. We highlighted this in a conversation with one of the curators, in which he talks about works of art that would not have been exposed without the

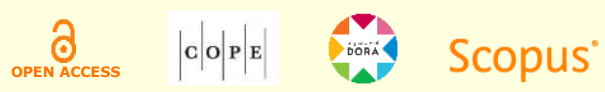


Kidnapped April Exhibition. Moreover, to exemplify this practice, we brought an excerpt from the interview with another organizer that usually works with high-end art.

"This gallery has a focus... which is modern art... that is to work with nationally known names. This is not bad ... But you see that there are works that would have never been exposed here, you know? Thus, they would never be seen here, in this gallery, but due to entering the movement, here they are..." (Interview, 2017, our translation).

Aligned to the discussion above, some of the spaces have departed from their own original meaning, as observed in the church that stopped being a church and became an art gallery. In addition, galleries exhibited works of art and artists that, if it had not been for the Kidnapped Exhibition, would never have entered there. The identity practices transgress and emancipate the Exhibition, putting even more in evidence the process of resistance where it is engaged. In this sense, the resistance process and rupture practice intertwined, in a constitutive mutuality, transformed and reorganized the daily life and the urbanity of the city.

According to Vaujany and Vaast (2014, p. 725), "different spatial practices might help align or realign organizational space and legitimacy claims". Thus, a constant legitimation of the arts organization shows the effects of the decisive role of the tales of space in the city organizing (Certeau, 1984). Besides that, the kidnapping can be understood as a way of legitimating spatial practices of rupture performed by the organization's actors (Certeau, 1984; Munro \& Jordan, 2013; Spicer \& Böhm, 2007; Thomas \& Davies, 2005; Vaujany \& Vaast, 2014).

These evidences are related to the tales of spaces that are animated by a dynamic contradiction that lies between the frontier (the space) and the bridge (the exteriority), punctuating a spatial blurring in these configurations where the organizational boundaries between frontier and bridges are porous, plural, differentiated, ambiguous, source of contestation, and objects of continuous negotiations. This process is understood from a clash of practices by which the agents (re)appropriate spaces in the city with effects in its organization. These pieces of evidence also emphasize the relation of constitutive mutuality between rupture and resistance perpetrated by the arts organization in the context of the city (Beyes \& Steyaert, 2012; Certeau, 1984; Fleming \& Spicer, 2007; Halford \& Leonard, 2005; Wapshott \& Mallett, 2012).

Finally, we observed in these tales of space the presence of lingering memory (Certeau, 1984). The kidnapping of the arts organization is closely related to a memory of previous editions and its history (Certeau, 1984; Chartier, 2011; Ipiranga \& Lopes, 2017). This can be noticed at the beginning of its manifesto: "With more than seven decades of existence, the April Exhibition is a traditional exhibition of great relevance that has always provided throughout its history an important artistic landscape in the state of Ceará and Brazil" (Fórum de Artes Visuais de Fortaleza, 2017, p. 1, our translation). Hence, we also claim that temporal and memorial practices are embedded in the disruptive spatial practices of today, in a way that "in the composition of the initial place, the world of the memory intervenes at the 'right moment' and produces modifications of the space" (Certeau, 1984, p. 84).

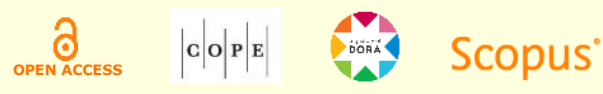


The Firmeza Museum, one of the spaces in a suburb area of the city included and (re)appropriated by the kidnapped arts organization, is an example of the action of that temporal and memorial practice. This museum is considered special by many of the artists, curators and organizers due to its historical legacy (Certeau, 1984; Chartier, 2011; Ipiranga \& Lopes, 2017; Vaujany \& Vaast, 2014). Two artists that were primordial to the beginning of the April Exhibition used to live and maintain their art workshops there. At the present day, the Firmeza Museum hosts a large collection of archives about the April Exhibition among other artistic installations and objects typical of Northeastern Brazil. Differently from the other spaces, the museum is located in a suburban neighborhood in the city, far from the other venues as we can see in the map below (Figure 3), evidencing the extension of the spatial practice network and its effects on the city organizing.

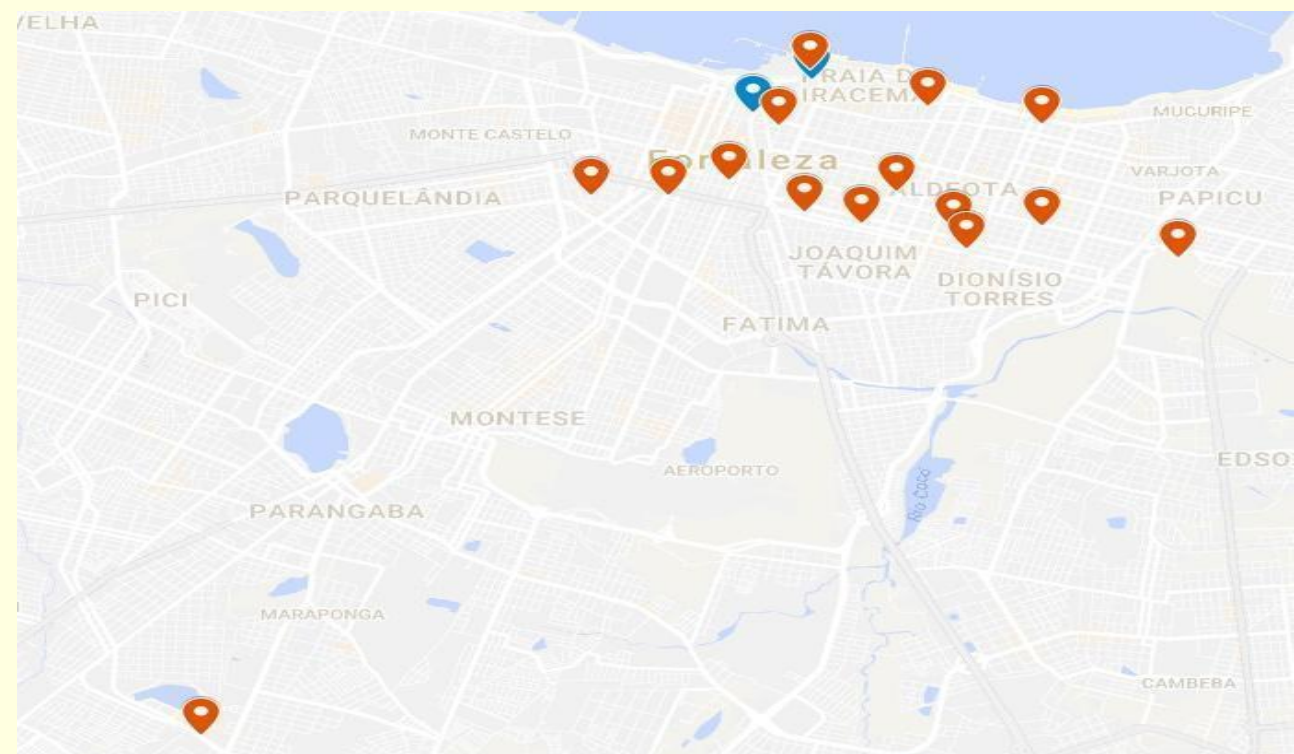

Figure 3. Place of Firmeza Museum and spacing processes in the city organizing Source: adapted from $68^{\circ}$ Salão de Abril Sequestrado. (n.d.). Mapa 680 Salão de Abril Sequestrado. Retrieved from https://www.google.com/maps/d/embed?mid=1vb_a7OjosOsSy5usCfwllO058W4

Furthermore, we also perceived the existence of memorial and temporal practices (Certeau, 1984; Chartier, 2011; Ipiranga \& Lopes, 2017) in the closing ceremony of the kidnapped arts organization that occurred in the Firmeza Museum, where, according to field notes from October 28,2017 , one of the artists begins the speech talking about the importance of the exhibition by saying that the April Exhibition is returning to its bosom, to its crib. In addition, one of the museum's employees said that the Firmeza Museum was born kidnapped, where she emphasized that this is the Firmeza Museum's life. She asked the participants to occupy it, speak about it, participate in it.

These practices displayed during the kidnapped arts organization characterized it as a "spatial legacy” (Vaujany \& Vaast, 2014), containing memory, objects and traces from previous April Exhibitions. Through these temporal and memorial practices, artists, curators and participants claimed not only organizational legitimacy (Vaujany \& Vaast, 2014) but also the historical meaning of the April Exhibition organizing.

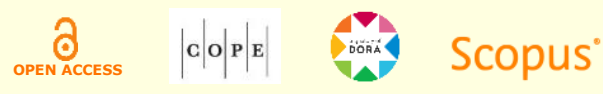




\section{Conclusions}

In this work, we performed a study considering the interlaced debate based on the creation of a set of spatial deviations, such as spacing and (re)appropriation processes in the context of city organizing. For this, we propose to understand the spatial practices of ruptures imbricated in the process of resistance in the kidnapping of an arts organization, the April Exhibition, an art exposition in the Brazilian city of Fortaleza. We assume that those ruptures come from a resistance process, and that it is enacted through a set of heterogeneous practices.

Through a set of practices, the kidnapping broke up with the hegemony of the public power established in the organizing of the April Exhibition. We perceive a network of heterogonous practices of rupture around the city, among them: discursive practices, tactical and strategic practices, spatial practices, artistic practices, identity practices, and temporal and memorial practices. This heterogeneous network acts as a spatial practice of rupture, whether it is institutional, political, geographical, artistic or symbolical dimensions.

Further, we observed that this network of spatial practices of ruptures, intertwined with the resistance processes carried out by the kidnapping of the Exhibition, represents a bridge that reaches and includes different spaces previously forgotten and disregarded by the former editions of the April Exhibition and by the municipal government. These movements of spacing and (re)appropriation made possible the emergence of new practiced spaces with effects in the city organizing. The topic evidenced in the results concerning the turning of peripheral districts of the city into arts organizations has marked an important movement that needs to be considered.

Hence, we noticed that the Kidnapped Exhibition itself created a context that favored the manifestations of the history of the April Exhibition. At first, the silence from the municipal government in organizing the 2017 edition of the arts organization. Next, the kidnapping of the April Exhibition and the need to legitimize it. Finally, the set of spaces through which the arts organization was (re)appropriating and the artists' own practices and organizers. All these pieces of evidence were essential to make the history of the April Exhibition emerge, often being told at every meeting, and still serving as a speech of legitimacy to the tales of space. In this sense, to deepen this research in the future, we suggest further research on this historical evidence that emerged from the arts organization's kidnapping.

With this study, we contribute to the enlargement of the interlaced debate of spatial practice, rupture and resistance, showing how the network of heterogeneous practices imbricated with a resistance process, performed by an arts organization in the city, can rupture with established power structures and the urban everyday life. In this sense, we intend to move forward the frontiers of Management and Organizational Studies by revealing the constitutive mutuality between resistance processes and rupture practices, capable of bringing new organizational forms to the city, which challenge the ways of organizing already established. 
We still contribute by broadening the discussion about the city as an open organization through, for example, an arts organization as shown in this study. In this context, we illuminate the relationship between resistance process and spatial practices of rupture as an organizational nexus of the city, suggesting a research agenda that contributes to critical research on these topics.

\section{References}

Beyes, T., \& Steyaert, C. (2012). Spacing organization: Non-representational theory and performing organizational space. Organization, 19(1), 45-61. https://doi.org/10.1177/1350508411401946

Carradini, S. (2018). An organizational structure of Indie Rock musicians as displayed by Facebook usage. Journal of Technical Writing and Communication, 48(2), 151-174. https://doi.org/10.1177/0047281616667677

Certeau, M. (1984). The practice of everyday life. London, UK: University of California Press.

Chartier, R. (2011). History, time, and space. Republics of Letters: A Journal for the Study of Knowledge, Politics, and the Arts, 2(2), 1-13. Retrieved from https://arcade.stanford.edu/sites/default/files/article_pdfs/roflv02i02_Chartier_060111_0.pdf

Clegg, S., \& Kornberger, M. (2006). Organising space. In S. Clegg, \& M. Kornberger (Eds.), Space, organizations and management theory (pp. 143-162). Copenhagen, Denmark: Liber and Copenhagen Business School Press.

Cooper, R. (1976). The open field. Human Relations, 29(11), 999-1017. https://doi.org/10.1177\%2F001872677602901101

Cooper, R., \& Fox, S. (1990). The texture of organizing. Journal of Management Studies, 27(6), 575-582. https://doi.org/10.1111/j.1467-6486.1990.tb00263.x

Costa, I. (2017). Enquanto setembro chegar... Jornal O Povo. Retrieved from https://www.opovo.com.br/jornal/vidaearte/2017/06/esperando-setembro-chegar.html

Cresswell, T., \& Merriman, P. (Eds.) (2011). Geographies of mobilities: Practices, spaces, subjects. Surrey, UK: Ashgate Publishing.

Czarniawska, B. (2007). Shadowing, and other techniques for doing fieldwork in modern societies. Frederksberg, Denmark: Copenhagen Business School Press.

Czarniawska, B. (2008). A theory of organizing. Cheltenham, UK: Edward Elgar Publishing.

Dale, K., \& Burrell, G. (2008). Spaces of organization and the organization of space. Basingstoke, UK: Palgrave Macmillan.

D'Astous, A., Colbert, F., \& Fournier, M. (2007). An experimental investigation of the use of brand extension and co-branding strategies in the arts. Journal of Services Marketing, 21(4), 231-240. https://doi.org/10.1108/08876040710758531

Détienne, M., \& Vernant, J. (2008). Métis. As astúcias da inteligência. São Paulo, Brazil: Odysseus Editora.

Estrigas, N. (1983). Fase renovadora na arte cearense. Fortaleza, Brazil: Edições Universidade Federal do Ceará.

Flach, L., \& Antonello, C. S. (2011). Organizações culturais e a aprendizagem baseada em práticas. Cadernos EBAPE.BR, 9(1), 156-176. https://doi.org/10.1590/s1679-39512011000100010

Fleming, P., \& Spicer, A. (2007). Contesting the corporation: Struggle, power and resistance in organizations. Cambridge, UK: Cambridge University Press.

Fórum de Artes Visuais de Fortaleza. (2017). 68 Salão de Abril Sequestrado. Retrieved from https://tinyurl.com/sequestradoconvocatoria

Goulart, S., Menezes, M., \& Gonçalves, J. (2002). Composição e características do campo organizacional dos museus e teatros da Região Metropolitana da Cidade de Recife. Proceedings of Encontro Nacional de Estudos Organizacionais, Recife, PE, Brazil, 2. 
Gouvêa, J. B., \& Ichikawa, E. Y. (2015). Alienação e resistência: Um estudo sobre o cotidiano cooperativo em uma feira de pequenos produtores do oeste do Paraná. Revista Gestão e Conexões, 4(1), 68-90. https://doi.org/10.13071/regec.2317-5087.2014.4.1.8015.68-90

Greig, G., Gilmore, C., Patrick, H., \& Beech, N. (2013). Arresting moments in engaged management research. Management Learning, 44(3), 267-285. https://doi.org/10.1177/1350507612443209

Halford, S., \& Leonard, P. (2005). Place, space and time: Contextualizing workplace subjectivities. Organization Studies, 27(5), 657-676. https://doi.org/10.1177/0170840605059453

Hall, P. (1988). Cities of tomorrow. London, UK: Basil Blackwell Ltd.

Ipiranga, A. S. R., \& Lopes, L. L. S. (2017). O organizar da estética espacial: Uma história táctil da praça dos leões. Sociedade, Contabilidade e Gestão, 12(1), 130-153. https://doi.org/10.21446/scg_ufrj.v12i1.13402

Johansson, M., \& Kociatkiewicz, J. (2011). City festivals: Creativity and control in staged urban experience. European Urban and Regional Studies, 18(4), 392-405. https://doi.org/10.1177/0969776411407810

Kornberger, M., \& Clegg, S. (2004). Bringing space back in: Organizing the generative building. Organization Studies, 25(7), p. 1095-1114. https://doi.org/10.1177/0170840604046312

Lefebvre, H. (1991). The production of space. Oxford, UK: Wiley-Blackwell.

Machado, P. F. (2011). Diálogos entre arte e público no espaço urbano: O 59॰ Salão de Abril e a experiência no Terminal do Papicu. In C. Vieira, \& K. M. Rodrigues, Arte contemporânea e seus públicos (pp. 64-81). Fortaleza, Brazil: Edições Demócrito Rocha.

Marcus, G. E. (1995). Ethnography in/of the world system: The emergence of multi-sited ethnography. Annual Review of Anthropology, 24(1), 95-117. https://doi.org/10.1146/annurev.an.24.100195.000523

Marins, S. R., \& Ipiranga, A. S. R. (2017). O organizar ampliado de práticas cotidianas. Farol - Revista de Estudos $\begin{array}{lllll}\text { Organizacionais } & \text { e } & \text { Sociedade, } & \text { 4(9), } & \text { 148-204. }\end{array}$ https://revistas.face.ufmg.br/index.php/farol/article/view/3224

Massey, D. (2005). For space. London, UK: Sage Publications.

Medeiros, J. R. L. (2012). Onde experimentar? Políticas Culturais em Revista, 5(2), 151-163. Retrieved from https://portalseer.ufba.br/index.php/pculturais/article/view/6911/4827

Munro, I., \& Jordan, S. (2013). 'Living space' at the Edinburgh Festival Fringe: Spatial tactics and the politics of smooth space. Human Relations, 66(11), 1497-1525. https://doi.org/10.1177/0018726713480411

Oliveira, J. S. D., \& Cavedon, N. R. (2017). Os circos contemporâneos como heterotopias organizacionais: Uma etnografia multissituada no contexto Brasil-Canadá. Revista de Administração Contemporânea, 21(2), $142-162$. https://doi.org/10.1590/1982-7849rac2017150047

O III Salão de Abril está sendo muito visitado pelo nosso povo. (1947, April 3). Unitário, 9.677.

Panayiotou, A., \& Kafiris, K. (2011). Viewing the language of space: Organizational space, power and resistance in popular films. Journal of Management Inquiry, 20(3), 264-284. https://doi.org/10.1177/1056492610389816

Rentschler, R., \& Potter, B. (1996). Accountability versus artistic development: The case for non-profit museums and performing arts organizations. Accounting, Auditing $\mathcal{E}$ Accountability Journal, 9(5), 100-113. https://doi.org/10.1108/09513579610151971

Rolim, H. (Org.) (2010). Salão de abril 1980-2009: De casa para o mundo do mundo para casa. Fortaleza, Brazil: Lumiar Comunicação e Consultoria.

Saraiva, L. A. S., \& Carrieri, A. P. (2012). Organização-cidade: proposta de avanço conceitual a partir da análise de um caso. Revista de Administração Pública, 46(2), 547-576.

68 Salão de Abril começa hoje, sem apoio da prefeitura. (2017, September 28). Jornal O Povo. Retrieved from https://www.opovo.com.br/jornal/vidaearte/2017/09/68-salao-de-abril-comeca-hoje-sem-apoio-da-prefeiturade-fortaleza.html 
68 Salão de Abril Sequestrado. (2017c). \#Aberturas Amanhã, 29/set às 17h, teremos a abertura na Casa Benfica, que tem curadoria de Beatriz [Facebook post]. Retrieved from https://www.facebook.com/68SalaodeAbrilSequestrado/posts/345826865876435

68 Salão de Abril Sequestrado. (2017a, August 24). Esse movimento demonstra a vontade de se fazer mais pelas Artes Visuais na cidade e também a clara insatisfação com a falta de atitude da Secultfor Fortaleza [Facebook status $\quad$ update]. $\quad$ Retrieved from https://www.facebook.com/68SalaodeAbrilSequestrado/posts/332721380520317

68 Salão de Abril Sequestrado. (2017b, September 12). Ontem tivemos o primeiro encontro de artistas, ontem foi na Galeria Multiarte, com os artistas que vão expor lá, que terá a curadoria de Bitu Cassundé. O encontro foi bastante produtivo e a ideia é que esses encontros gerem outros [Facebook post]. Retrieved from https://www.facebook.com/68SalaodeAbrilSequestrado/posts/339782666480855

Spicer, A., \& Böhm, S. (2007). Moving management: Theorizing struggles against the hegemony of management. Organization Studies, 28(11), 1667-1698. https://doi.org/10.1177/0170840606082219

Taylor, S., \& Spicer, A. (2007). Time for space: A narrative review of research on organizational spaces. International Journal of Management Reviews, 9(4), 325-346. https://doi.org/10.1111/j.1468-2370.2007.00214.x

Terdiman, R. (2001). The marginality of Michel de Certeau. The South Atlantic Quaterly, 100(2), $399-421$. https://doi.org/10.1215/00382876-100-2-399

Thomas, R., \& Davies, A. (2005). Theorizing the micro-politics of resistance: New public management and managerial identities in the UK public services. Organization Studies, 26(5), 683-706. https://doi.org/10.1177/0170840605051821

Thrift, N. (2007). Non-representational theory: Space, politics, affect. London, UK: Routledge.

Vaujany, F.X. de, \& Vaast, E. (2014). If these walls could talk: The mutual construction of organizational space and legitimacy. Organization Science, 25(3), 713-731. https://doi.org/10.1287/orsc.2013.0858

Wapshott, R., \& Mallett, O. (2012). The spatial implications of homeworking: A Lefebvrian approach to the rewards and challenges of home-based work. Organization, 19(1), 63-79. https://doi.org/10.1177/1350508411405376

Yuk-kwan Ng, R., \& Höpfl, H. (2011). Objects in exile: The intimate structures of resistance and consolation. Journal of Organizational Change Management, 24(6), 751-766. https://doi.org/10.1108/09534811111175733

\section{Author contributions}

$1^{\text {st }}$ author: conceptualization (lead), data curation (lead), formal analysis (equal), methodology (equal), writingoriginal draft (lead), writing-review and editing (lead).

$2^{\text {nd }}$ author: conceptualization (equal), data curation (equal), formal analysis (equal), methodology (equal), writingoriginal draft (equal), writing-review and editing (equal).

$3^{\text {rd }}$ author: conceptualization (equal), data curation (equal), formal analysis (equal), methodology (equal), writingoriginal draft (equal), writing-review and editing (equal)

$4^{\text {th }}$ author: conceptualization (equal), data curation (equal), formal analysis (equal), methodology (equal), writingoriginal draft (equal), writing-review and editing (equal). 


\section{Authors}

\section{Mariana Maia Bezerra}

Universidade Estadual do Ceará, Centro de Estudos Sociais Aplicados

Avenida Dr. Silas Muguba, 1700, Campus do Itaperi, 60714-110, Fortaleza, CE, Brazil marianamaiab7@gmail.com

(iD) http://orcid.org/0000-0002-9217-0052

\section{Luma Louise Sousa Lopes}

Universidade Estadual do Ceará, Centro de Estudos Sociais Aplicados

Avenida Dr. Silas Muguba, 1700, Campus do Itaperi, 60714-110, Fortaleza, CE, Brazil lumalouise@gmail.com

(iD) http://orcid.org/0000-0003-2961-4041

\section{Joelma Soares da Silva}

Universidade Estadual do Ceará, Centro de Estudos Sociais Aplicados

Avenida Dr. Silas Muguba, 1700, Campus do Itaperi, 60714-110, Fortaleza, CE, Brazil joelma.soares@ufc.br

(iD) http://orcid.org/0000-0003-4591-0377

\section{Ana Sílvia Rocha Ipiranga}

Universidade Estadual do Ceará, Programa de Pós-Graduação em Administração

Avenida Abolição 2480/1004, Meireles, 60165-080, Fortaleza, CE, Brazil

anasilviaipi@uol.com.br

(iD) http://orcid.org/0000-0001-8095-6800 